\title{
КОНЦЕПТУАЛЬНІ СКЛАДОВІ ЕКОЛОГІЧНОГО МЕНЕДЖМЕНТУ АГРАРНОГО ВИРОБНИЦТВА
}

\section{CONCEPTUAL COMPONENTS OF ENVIRONMENTAL MANAGEMENT OF AGRICULTURAL PRODUCTION}

\author{
Пітель Ніна Якимівна \\ кандидат економічних наук, доцент, \\ Уманський національний університет садівництва \\ ORCID: https://orcid.org/0000-0002-5320-1522
}

\author{
Pitel Nina \\ Uman National University of Horticulture
}

\begin{abstract}
Стаття присвячена вивченню концептуальних елементів екологічного менеджменту аграрного виробництва. Обґрунтовано об'єктивну необхідність фрормування механізмів екологічного управління як дієвого інструмента розвитку висококонкурентного аграрного виробництва. Проаналізовано поточні витрати на охорону навколишнього середовища за видами природоохоронних заходів в Україні та динаміку обсягів утворення відходів зокрема, у сільському, лісовому і рибному господарстві. Встановлено, що сучасна концепція екологічного менеджменту об'єднує проблеми управління екологічними процесами і базується на економіко-соціальній і психологічній мотивації узгодження й гармонізації взаємовідносин людини і суспільства із природою. Систематизовано основні риси екологічної спрямованості аграрного виробництва й об'єктивні причини впровадження екологічного менеджменту. Визначено концептуальні складові екологічного менеджменту аграрного виробництва.

Ключові слова: екологічний менеджмент, концепція, управління, аграрне виробництво, концепція екологоорієнтованого управління.
\end{abstract}

Статья посвящена изучению концептуальных элементов экологического менеджмента аграрного производства. Обоснованно объективную необходимость фоормирования механизмов экологического управления как действенного инструмента развития высококонкурентного аграрного производства. Проанализированы текущие затраты на охрану окружающей среды по видам природоохранных мероприятий в Украине и динамика объемов образования отходов в частности, в сельском, лесном и рыбном хозяйстве. Установлено, что современная концепция экологического менеджмента объединяет проблемы управления экологическими процессами и базируется на экономико-социальной и психологической мотивации согласования и гармонизации взаимоотношений человека и общества с природой. Систематизированы основные черты экологической направленности аграрного производства и объективные причины внедрения экологического менеджмента. Определены концептуальные составляющие экологического менеджмента аграрного производства.

Ключевые слова: экологический менеджмент, концепция, управление, аграрное производство, концепция экологоориентированного управления.

This article is devoted to the study of conceptual elements of ecological management of agricultural production. The objective necessity of formation of ecological management mechanisms as an effective tool of development and formation of highly competitive agricultural production is substantiated. The current costs of environmental protection by types of environmental measures in Ukraine and the dynamics of waste generation in agriculture, forestry and fisheries are analyzed. The study suggests that environmental management contributes to the greening of agricultural production, protection and reproduction of land resources, rational use of them. It is established that the modern concept of environmental management combines problems of environmental management and it is based on economic, social and psychological motivation to harmonize the relationship between human and society with nature. The main features of the ecological orientation of agricultural production and the objective reasons for the introduction of environmental management are systematized. The conceptual components of ecological management of agricultural production are determined. Among them are the following: potential possibility and necessity of managing ecological processes; specification of the environment and object of management; formulation and implementation of the main goal of management; infrastructure and functional content of environmental management, its principles, methodology; organization of environmental management; systems, mechanisms and technologies of agricultural management; strategy and effectiveness of environmental management. It is substantiated that high 
competitiveness of business entities is possible only if environmentally friendly production and minimization of harmful effects on the environment. Therefore, it is important to stimulate environmental initiatives, to consider environmental restrictions through the prism of new opportunities for agribusiness development, to develop environmental controlling and audit.

Keywords: ecological management, concept, management, agricultural production, concept of ecologically oriented management.

Постановка проблеми. Інтеграція економіки аграрної галузі України до світової економіки актуалізує проблеми виробництва й експорту екологічно безпечної сільськогосподарської продукції. Досягти цього можна лише за умови раціонального й ефективного використання наявних природних ресурсів у процесі організації й ведення сільськогосподарського виробництва. За таких реалій виникає об'єктивна необхідність формування й реалізації в аграрній сфрері економіки країни механізмів екологоорієнтованого управління, яке забезпечуватиме передумови для стабільного і збалансованого розвитку галузі.

Аналіз останніх досліджень і публікацій. Теоретичні, методологічні і прикладні аспекти екологічного управління тривалий час перебувають в полі зору багатьох науковців. Зокрема, проблематику екологічного менеджменту вивчали Кожушко Л.Ф., Скрипчук П.М., Кірсанова Т.О., Дуднікова І.І., Федулова Л.І., Купалова Г.І. та інші. Їх наукові здобутки спрямовані на вивчення питань державної екологічної політики й аудиту, впровадження принципів «зеленого» бізнесу, формування ефективної системи екологічного менеджменту, його правового регулювання. Дослідження останніх років присвячені вивченню сутності і складових екологічного менеджменту [1], впливу системи екологічного менеджменту на підвищення конкурентоспроможності українських підприємств [2], інсрормаційному забезпеченню екологічного управління [3], необхідності впровадження екологічного менеджменту в практичну діяльність вітчизняних підприємств [4-6].

Виділення невирішених раніше частин загальної проблеми. Наявні прогалини у розумінні об'єктивної необхідності формування цілісної і збалансованої концепції екологічного менеджменту в аграрній сфрері спонукають до подальших досліджень. Адже зазначені питання донині не знайшли належного відображення, а це, в свою чергу, залишає поле для дискусій стосовно включення до концепції екологоорієнтованого управління різних за роллю і значенням елементів.

Формулювання цілей статті (постановка завдання). Метою нашої статті $€$ дослід- ження концептуальних елементів екологічного менеджменту аграрного виробництва для формування прогресивної суспільної свідомості та нових підходів і концепцій управління, які передбачають інтегрування людини і природи.

Виклад основного матеріалу дослідження. Процеси ринкової трансорормації аграрної ссрери економіки України не сприяли формуванню ефрективного механізму економічного розвитку з урахуванням екологічного стану країни та їі регіонів. Тому нині вкрай важливо досліджувати і розвивати напрями вирішення екологічних проблем на засадах інноваційних підходів до нових наукових досліджень у ссрері сучасного управління. Ефрективним механізмом за таких умов може стати екологічний менеджмент, організований на інтегруванні комплексних підходів до аналізу й оцінки аграрного сектора вітчизняної економіки. Отже варто відзначити нинішню нагальну необхідність формування механізмів екологічного управління як дієвого інструмента стійкого розвитку і становлення висококонкурентного аграрного виробництва в Україні.

Впродовж останніх років науково-технічний прогрес об'єктивно стимулює виробничі бізнес-процеси, зумовлює запровадження інноваційних технологій, ріст виробничих потужностей, посилення впливу виробництва на навколишнє середовище як на локальному, так і глобальному рівнях. За таких умов відбувається погіршення екологічного середовища вітчизняного аграрного бізнесу, і разом з тим зростають вимоги до діючої системи управління економічними процесами.

Екологічний менеджмент у будь якій сорері економіки країни і на будь якому рівні має передбачати фрормування збалансованої концепції управління розвитком природи і суспільства, а також сучасного виробництва, що базується на засадах раціонального використання природних ресурсів, мінімізації забруднення навколишнього середовища і максимального збереження стійкої рівноваги наявних екосистем. Отже, екологічний менеджмент - це сучасний тип управління, принципово орієнтований на формування й розвиток екологічної культури життєдіяльності 
людини й екологічного виробництва. Цей підхід до управління базується на соціальноекономічному і психологічному мотивуванні гармонізації взаємин людини із природою [7]. Це інструмент екологічного планування, організації, регулювання, мотивування і контролю, впровадження якого сприятиме узагальненню, оптимізації і підвищенню ефективності підприємницької діяльності, спрямований на збалансоване споживання матеріалів і енергії з природних джерел та зниження негативного впливу на навколишнє середовище і здоров'я населення [2, с. 125].

На рівні підприємства екологічний менеджмент - це частина загальної системи управління, що об'єднує планування, організаційну структуру, процедури, процеси, практичну діяльність і ресурси, необхідні для фоормування, впровадження і реалізації цілей i завдань екологічної політики, її уточнення і коригування [8, с. 101; 9, с. 54].

Предметом екологічного управління мають бути, насамперед, ресурсозберігаючі і природоохоронні напрями роботи суб'єкта підприємницької діяльності, а кінцевою метою - мінімізація несприятливого впливу бізнес-процесів на навколишнє середовище, забезпечення високого рівня екологічності виробництва і споживання продукції, або послуг. Важливо констатувати, що реалізація цих завдань повинна узгоджуватись із збереженням пріоритетних цілей бізнесу, включаючи високу конкурентоспроможність продукції і послуг.

В сучасних реаліях екологічний менеджмент розширює межі і стратегічні пріоритети управління, адже разом із виробничими процесами охоплює навколишнє середовище, і в подальшому, при фрормуванні тактичних і стратегічних планів, екологічна проблематика розглядається у взаємозв'язку з іншими завданнями бізнес-діяльності, а екологічні витрати впливають на прибутковість підприємництва і стають невід'ємною інтегральною частиною бізнесу.

Система заходів екологічного менеджменту повинна бути реалізована на всіх рівнях управління - починаючи із підприємств і організацій; галузей, що відображають особливості видів господарської діяльності; регіонів і територій, які мають неоднакові обсяги забруднення та країни загалом. Адже саме рівень управління визначатиме пріоритети і окреслюватиме напрями роботи з поліпшення навколишнього природного середовища й підвищення якості життя населення та конкретизуватиме критерії оцінювання есрективності заходів з екологічного менеджменту.

Впродовж останніх двадцяти років в Україні поточні витрати на охорону навколишнього природного середовища зросли більше ніж у

Поточні витрати на охорону навколишнього природного середовища в Україні,

Таблиця 1 за видами природоохоронних заходів ${ }^{*}$, у фактичних цінах, млн. грн

\begin{tabular}{|c|c|c|c|c|c|c|}
\hline \multirow[b]{2}{*}{ Роки } & \multirow[t]{2}{*}{ Усього } & \multicolumn{5}{|c|}{ У тому числі на } \\
\hline & & $\begin{array}{c}\text { охорону } \\
\text { атмосорерного } \\
\text { повітря } \\
\text { і проблеми } \\
\text { зміни клімату }\end{array}$ & $\begin{array}{c}\text { очищення } \\
\text { зворотних } \\
\text { вод }\end{array}$ & $\begin{array}{l}\text { поводження } \\
\text { з відходами }\end{array}$ & $\begin{array}{c}\text { захист і } \\
\text { реабілітацію } \\
\text { Ґрунту, } \\
\text { підземних і } \\
\text { поверхневих } \\
\text { вод } \\
\end{array}$ & $\begin{array}{c}\text { інші } \\
\text { заходи }\end{array}$ \\
\hline 2000 & 2618,4 & 350,4 & 1715,3 & 279,2 & 66,9 & 206,5 \\
\hline 2005 & 5313,6 & 877,4 & 2910,9 & 925,5 & 121,7 & 478,1 \\
\hline 2010 & 10366,6 & 1314,8 & 5035,5 & 2599,6 & 476,3 & 940,4 \\
\hline 2015 & 16915,5 & 1519,8 & 6644,3 & 6801,9 & 1152,7 & 796,8 \\
\hline 2016 & 19098,2 & 1760,6 & 7800,1 & 6719,6 & 1197,2 & 1620,8 \\
\hline 2017 & 20466,4 & 2104,3 & 8065,3 & 7508,2 & 983,8 & 1804,9 \\
\hline 2018 & 24318,0 & 2897,7 & 9623,5 & 8830,2 & 1288,4 & 1678,3 \\
\hline 2019 & 27480,2 & 2963,9 & 10872,7 & 10227,1 & 1583,9 & 1832,5 \\
\hline $\begin{array}{l}2019 \text { p. }+,- \\
\text { до } 2000 \text { p. }\end{array}$ & 24861,8 & 2613,5 & 9157,4 & 9947,9 & 1517,0 & 1626,0 \\
\hline $\begin{array}{c}2019 \text { р. до } \\
2000 \text { р., разів }\end{array}$ & 10,5 & 8,5 & 6,3 & 36,6 & 23,7 & 8,9 \\
\hline
\end{tabular}

Примітка. * - систематизовано і побудовано за даними [10]; починаючи із 2014 р. дані наведені без урахування тимчасово окупованої території Автономної Республіки Крим, м. Севастополя та частини тимчасово окупованих територій у Донецькій та Луганській областях 
десять разів (табл. 1). Їх обсяг у 2019 р. склав 27,5 млрд. грн у срактичних цінах, тоді як у 2000 р. дорівнював лише 2,6 млрд. грн. За видами природоохоронних заходів у 2019 р. найбільші обсяги витрат спрямовуються на очищення зворотних вод (10,9 млрд. грн., що складає 39,6\% від загального обсягу) і поводження 3 відходами (10,2 млрд. грн., $37,2 \%)$, а найменші - на захист і реабілітацію ґрунту, підземних і поверхневих вод (лише 1,6 млрд. грн., або 5,8\%).

За аналогічний період суттєво зростали й обсяги утворення відходів: із 184,2 млн. т у 2000 р. до 441,5 млн. т у 2019 р., або в 2,4 раза (рис. 1). Набагато вищими темпами порівняно із всіма сорерами економіки України зростали обсяги утворення відходів у сільському, лісовому і рибному господарстві.

Впродовж 2000-2019 рр. їх обсяги зросли із 1,3 до 6,8 млн. т, або більше ніж у п'ять разів. Отже, саме дані галузі потребують розробки й реалізації ефективної концепції екологоорієнтованого управління, яке забезпечуватиме передумови для стабільного розвитку.
Варто також зауважити позитивну тенденцію значного перевищення загальних поточних витрат на охорону навколишнього природного середовища в Україні порівняно із обсягами утворення відходів. Це вказує на посилення уваги з боку держави і бізнесу до природоохоронних заходів, усвідомлення їх ролі і значення для розвитку економіки і підвищення конкурентоспроможності вітчизняних підприємств на світовому ринку.

Нині екологія виокремлює нові орієнтири і напрями аграрного підприємництва, тому саме вона має стати поштовхом до розвитку нових технологій і нових тенденцій взаємодії аграрного виробництва і природи. Тому фрормування механізмів управління екологічними процесами покликаний забезпечити саме екологічний менеджмент. Цей тип управління сприятиме раціональному природокористуванню, екологізації аграрного виробництва, охороні та відтворенню земельних ресурсів.

Важливим аспектом екологічно орієнтованого управління аграрної ссрери $€$ інсрормованість про екобезпечні технології, моніторинг

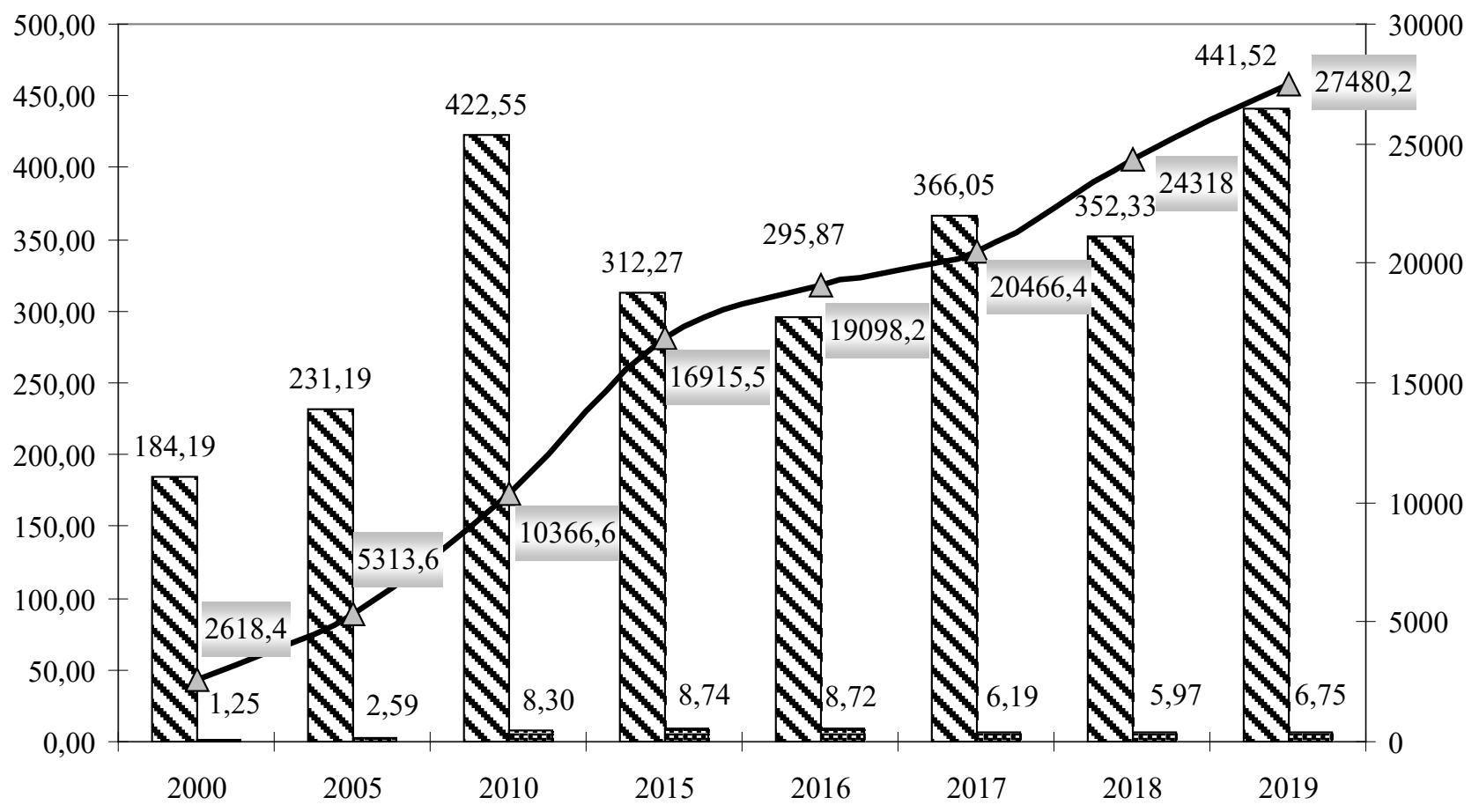

는 Уворено відходів, усього, млн. т

у тому числі в сільському, лісовому та рибному господарстві, млн. т

$\triangle-$ Поточні витрати на охорону навколишнього природного середовища (у фактичних цінах; млн. грн)

Рис. 1. Динаміка обсягів утворення відходів і поточні витрати на охорону навколишнього природного середовища в Україні*

Примітка. * - систематизовано і побудовано за даними [10]; починаючи із 2014 р. дані наведені без урахування тимчасово окупованої території Автономної Республіки Крим, м. Севастополя та частини тимчасово окупованих територій у Донецькій та Луганській областях 
відповідності стану земельних ресурсів екологічним нормам, врегулювання техногенного навантаження. Адже в умовах конкуренції перемагають підприємства, які більш гнучко й оперативно реагують на зміни, тому система інформаційного забезпечення екологічного менеджменту має відповідати сучасним умовам і передбачати доступ до оперативних даних про стан довкілля, їх збір, обробку і належне зберігання [3, с. 39].

Концепція екологічного менеджменту - це система поглядів, принципи розуміння явищ і процесів, комплекс ключових положень, що визначають організацію природоохоронної діяльності на всіх ієрархічних рівнях - від суб'єкта підприємництва - до глобального бізнес-середовища. Зазначені положення передбачають наступне [7]:

1. Без екологічної стійкості неможливе довгострокове економічне зростання. Тобто природоохоронна діяльність потребує значних витрат, але разом 3 тим забезпечує одержання конкурентних переваг.

2. Необхідна чітка стратегія і організаційна структура, яка включатиме екологічну складову до всіх напрямів і видів діяльності (починаючи з виникнення ідей і їх наукового обґрунтування і закінчуючи виробництвом і просуванням продукції.

3. Важлива постійна співпраця $з$ громадськістю, адже без цього успішне і соціально відповідальне підприємництво неможливе.

Сучасна концепція екологічного менеджменту об'єднує весь спектр проблем управління екологічними процесами і базується на економіко-соціальній і психологічній мотивації узгодження і гармонізації взаємовідносин людини і суспільства із природою. 3 огляду на це стратегія управління повинна збалансувати цілісний комплекс інструментів і методів для інноваційного розвитку виробництва, розробки і запровадження нових технологій, фрормування прогресивної суспільної свідомості, i, що особливо важливо - нових підходів і концепцій управління, які передбачають інтегрування людини і природи.

Отже, можна стверджувати, що екологічну спрямованість виробництва визначають такі риси: пріоритетна ціль - інтегрування і гармонізація взаємовідносин людини і природи та формування системи екологічного менеджменту як типу управління, яке відповідає потребам і особливостям сучасного підприємництва; безвідходність виробничих процесів на основі диверсисрікації виробництва та інновацій; запровадження екологічно спри- ятливих технологій; екологізація ринку, адже головним фактором економічного розвитку i прибутковості $\epsilon$ якість і екологічність продукції; формування екологічно орієнтованої корпоративної культури.

Екологічний менеджмент - це сучасна концепція управління суспільством і виробництвом, яка відповідає вимогам часу і базується на цілях, критеріях і мотивах розвитку соціоприродних процесів $[11$, с. 61]. Необхідність його запровадження визначається рядом об'єктивних причин, серед яких: погіршення екологічної ситуації, криза навколишнього середовища і закономірні тенденції розвитку сучасного виробництва, серед них наступні: фрормування екологічної свідомості і світогляду; розвиток науково-технічного прогресу; поділ країн світу на виробників і споживачів небезпечних відходів; посилення впливу виробництва не лише на регіональну природу, а й на загально світовий простір; диференціювання регіонального розміщення виробництва; нарощування виробничих потужностей у відповідності до потреб нових технологій [11, с. 61-62].

Концепція екологічного менеджменту аграрної сорери включає наступні елементи [11, c. 62-63]:

1. Обґрунтування потенційної можливості і об'єктивної необхідності управління екологічними процесами агробізнесу на всіх ієрархічних рівнях.

2. Визначення середовища і об'єкта управління - взаємодії людини і суспільства із природою.

3. Формулювання і подальшу реалізацію головної цілі управління - якісно нові умови життєдіяльності людини.

4. Інфрраструктура екологічного менеджменту. Узгодження масштабів управління i проблем аграрного виробництва, їх взаємодія на всіх ієрархічних рівнях.

5. Функціональний зміст екологічного менеджменту, його принципи й методологічні засади.

6. Організацію екологічного менеджменту аграрного виробництва.

7. Системи, механізми і технології управління, які враховують специфріку аграрної ссрери.

8. Стратегію і ефрективність екологічного менеджменту.

Формуючи концептуальні засади екологічного менеджменту аграрної сорери важливо враховувати його основні принципи, серед яких пріоритетність і своєчасність вирішення 
екологічних проблем, а також жорстка відповідальність за екологічні наслідки від прийнятих рішень. Їх дотримання базується на тому, що всі проблеми і завдання вирішуються через призму екологічних цілей. Отже, можна стверджувати, що висока конкурентоздатність суб'єктів підприємництва можлива лише за умови екологічно безпечного виробництва і мінімізації шкідливого впливу на навколишнє середовище. Для реалізації означених принципів важливо стимулювати природоохоронні ініціативи, розглядати екологічні обмеження через призму нових можливостей для розвитку агробізнесу, розвивати екологічний контролінг і аудит [1, с. 50].

Висновки. Проведене дослідження дозволяє стверджувати, що екологічний менеджмент сприяє екологізації аграрного виробництва, охороні та відтворенню земельних ресурсів, раціональному природокористуванню і забезпечує фрормування дієвих механізмів управління екологічними проце- сами в умовах висококонкурентного аграрного виробництва в Україні. Зважаючи на це сучасна концепція екологічного менеджменту повинна базуватись на економіко-соціальній і психологічній мотивації узгодження й гармонізації взаємовідносин людини і суспільства із природою. Ії̈ визначальними елементами мають бути наступні: потенційна можливість і необхідність управління екологічними процесами; конкретизація середовища і об'єкту управління; фрормулювання і реалізація головної цілі управління; інфрраструктура і фрункціональний зміст екологічного менеджменту, його принципи, методологія; організація екологічного менеджменту; системи, механізми і технології управління аграрної сорери; стратегія і ефрективність екологічного менеджменту.

Подальші дослідження варто спрямувати на обґрунтування стратегічних пріоритетів для формування механізмів розвитку екологічного менеджменту в аграрному бізнессередовищі.

\section{СПИСОК ВИКОРИСТАНИХ ДЖЕРЕЛ:}

1. Демяненко К.А. Сутність та складові системи екологічного менеджменту. Європейські перспективи. 2015. Вип. 6. С. 47-52.

2. Сагірова А.С. Вплив системи екологічного менеджменту на підвищення конкурентоспроможності українських підприємств. Стратегія розвитку України. 2017. № 2. С. 125-129.

3. Могильницька А.М. Інформаційне забезпечення екологоорієнтованого управління аграрного виробництва. Агросвіт. 2020. № 24. C. 37-41. DOI: https://doi.org/10.32702/2306-6792.2020.24.37

4. Білявська Ю.В. Екологічний менеджмент підприємства. Економіка України. 2016. № 4. С. 104-111.

5. Кірейцева О.В., Сокол Л.М. Екологічні аспекти сільськогосподарського виробництва. Економіка АПК. 2017. № 7. С. 29-36.

6. Лесь А.В., Ращенко А.В., Фітісов А.М. Ефективність системи екологічного менеджменту на підприємствах лісопромислового комплексу. Агросвіт. 2020. № 19-20. С. 69-74. DOI: https://doi.org/10.32702/23066792.2020.19-20.69

7. Екологічний менеджмент на підприємстві (н.д.). URL: http://childflora.org.ua/?page_id=66 (дата звернення: 12.06.2021).

8. Siebert H. (1998) Economics of environmental theory and policy. Berlin : Springer, $187 \mathrm{p}$.

9. Soderbaum P. (2000) Ecological Economics: A Political Economics Approach to Environment and Development. London : Earthscan, $287 \mathrm{p}$.

10. Державна служба статистики України (н.д.). URL: http://www.ukrstat.gov.ua/ (дата звернення: 12.06.2021).

11. Шлапак H.С. (н.д.). Концепція екологічного менеджменту. URL: http://eir.pstu.edu/bitstream/handle/12345 6789/10242/\%D0\%92\%D0\%B5\%D1\%81\%D1\%8C\%20\%D1\%84\%D0\%B0\%D0\%BA\%D1\%83\%D0\%BB\%D1\%8C \%D1\%82\%D0\%B5\%D1\%82_p57-61.pdf?sequence=1 (дата звернення: 12.06.2021).

\section{REFERENCES:}

1. Demianenko, K.A. (2015) Sutnist ta skladovi systemy ekolohichnoho menedzhmentu [The essence and components of the environmental management system]. Yevropeiski perspektyvy - European perspectives, 6, 47-52. (in Ukrainian)

2. Sahirova, A.S. (2017) Vplyv systemy ekolohichnoho menedzhmentu na pidvyshchennia konkurentospromozhnosti ukrainskykh pidpryiemstv [The impact of the environmental management system on increasing the competitiveness of Ukrainian enterprises]. Stratehiia rozvytku Ukrainy - Development strategy of Ukraine, 2, 125-129. (in Ukrainian) 
3. Mohylnytska, A.M. (2020) Informatsiine zabezpechennia ekolohooriientovanoho upravlinnia ahrarnoho vyrobnytstva [Information support of ecologically oriented management of agricultural production]. Ahrosvit - Agrosvit, 24, 37-42. DOI: https://doi.org/10.32702/2306-6792.2020.24.37 (in Ukrainian)

4. Biliavska, Yu.V. (2016) Ekolohichnyi menedzhment pidpryiemstva [Environmental management of the enterprise]. Ekonomika Ukrainy - Ukraine economy, 4, 104-111. (in Ukrainian)

5. Kireitseva, O.V. \& Sokol, L.M. (2017) Ekolohichni aspekty silskohospodarskoho vyrobnytstva [Ecological aspects of agricultural production]. Ekonomika APK - Economics of agro-industrial complex, 7, 29-36. (in Ukrainian)

6. Les, A., Rashchenko, A. \& Fitisov, A. (2020) The efficiency of the environmental management system at the enterprises of the timber industry [The environmental management system efficiency at the timber industry enterprises]. Ahrosvit - Agrosvit, 19-20, 69-74. DOI: https://doi.org/10.32702/2306-6792.2020.19-20.69 (in Ukrainian)

7. Ekolohichnyi menedzhment na pidpryiemstvi [Environmental management at the enterprise] Retrieved from: http://childflora.org.ua/?page_id=66 (accessed 12 June 2021). (in Ukrainian)

8. Siebert, H. (1998) Economics of Environmental Theory and Policy. Berlin: Springer.

9. Soderbaum, P. (2000) Ecological Economics: A Political Economics Approach to Environment and Development. London: Earthscan.

10. Derzhavna sluzhba statystyky Ukrainy [State Statistics Service of Ukraine] Retrieved from http://www.ukrstat.gov.ua/ (accessed 12 June 2021). (in Ukrainian)

11. Shlapak, N.S. (n.d.). Kontseptsiia ekolohichnoho menedzhmentu [Environmental management concept] Retrieved from: http://eir.pstu.edu/bitstream/handle/123456789/10242/\%D0\%92\%D0\%B5\%D1\%81\%D1\%8C\%20 \%D1\%84\%D0\%B0\%D0\%BA\%D1\%83\%D0\%BB\%D1\%8C\%D1\%82\%D0\%B5\%D1\%82_p57-61.pdf?sequence=1 (accessed 12 June 2021). (in Ukrainian) 